Tropical Agricultural Pesearch \& Extension 22 (1 \& 2): 2019

\title{
EFFECT OF DIFFERENT SOIL NITROGEN LEVELS ON GROWTH, YIELD AND GRAIN FILLING RATE OF RICE (Oryza sativa L.) ELITE BREEDING LINE AT 081078 AND VARIETY AT 362
}

\author{
Kumara $\mathrm{KHCH}^{*}$ and Hafeel RF \\ Rice Research Station, Department of Agriculture, Ambalantota, Sri Lanka
}

\begin{abstract}
Grain filling rate, yield and 1000 grain weight are very important traits to determine the different nitrogen levels of response for different rice varieties. This study will investigate the rate of grain filling, grain yield and 1000 grain weight, and some quality parameters of one elite breeding line (At 08 1078) and standard variety (At 362) grown at five different nitrogen $(N)$ levels $\left(0,50,100,150 \& 200 \mathrm{~kg} \mathrm{~N} \mathrm{ha}^{-1}\right)$ under irrigated water condition in the low country dry zone of Sri Lanka. A split-plot experimental design was used in this experiment with three replicates. The gross plot and net plot area were $18 \mathrm{~m}^{2}$ and $12.96 \mathrm{~m}^{2}$ of each experimental unit. Main plots were separated by a ridge $(40 \mathrm{~cm}$ in width). The thousand-grain weight of each experimental unit from heading to harvesting was recorded at the 4-day interval to inspect the grain filling rate. Irrespective of the variety, grain filling commenced after four days from the day of heading and the rate of grain filling depended on the rate of nitrogen application on each experimental unit. Rice fertilized with $\geq 100 \mathrm{~kg} \mathrm{~N} \mathrm{ha}^{-1}$ had a high grain filling rate and the period of grain filling increased in both varieties. Application of $100 \mathrm{~kg} \mathrm{~N} \mathrm{ha}^{-1}$ was recognized as the optimum level for grain filling. Further increment of soil nitrogen (150 or $\left.200 \mathrm{~kg} \mathrm{~N} \mathrm{ha}^{-1}\right)$ has not significantly affected the grain filling rate of the paddy. In addition, the significant highest grain yield, grain hardness, brown rice content, grain length and width were recorded at $100 \mathrm{~kg} \mathrm{~N} \mathrm{ha}^{-1}$. It can be concluded that the $\mathrm{N}$ level of $100 \mathrm{~kg} \mathrm{~N} \mathrm{ha}^{-1} \mathrm{was}_{\text {found }}$ for yield response and grain filling to be the best rate for both elite line At 081078 and the variety At 362 .
\end{abstract}

Keywords: Grain filling, Grain weight, Growth parameters, Nitrogen, Rice

\section{INTRODUCTION}

Adequate supplies of nutrients for rice crops play a major role in realizing the yield potential. Moreover, the profitability of intensive rice production depends on fertilizer application (Yoseftabar 2013). Among the nutrients, nitrogen $(\mathrm{N})$ is required in comparatively greater quantities than other essential nutrients. Nitrogen plays a vital role in the growth and consequently the yield of crops. Apart from being a part of proteins, $\mathrm{N}$ is an essential component of chlorophyll; a chemical crucial for the life-sustaining process, photosynthesis. Qiao-gang et al (2013) reported that deficiency of soil nitrogen is one of the main limiting factors for achieving high rice yield. Due to that con-

*Corresponding author: harsha.hewage@yahoo.com stant replenishment through extraneous nitrogen inputs becomes mandatory for optimal yield. However, within the soil, the included nitrogen undergoes several complex physical and chemical transformations, which may decrease or increase the availability of nitrogen fertilizer to the plant. Rice varieties may respond differently to $\mathrm{N}$ fertilizer. Rice cultivars under high $\mathrm{N}$ fertilizer applications may not be suitable for soils with low $\mathrm{N}$ status. Even after the application of high rates of fertilizer $\mathrm{N}$ to rice, expected yield levels might not be obtained. If plant $\mathrm{N}$ status can be increased without lodging or increasing the incidence of pests and diseases, a significant increase in yield requires increased sink capacity, maintenance of high leaf $\mathrm{N}$ content and a longer 
grain filling duration. Rice varieties differ in their ability to extract soil and fertilizer $\mathrm{N}$ and in its distribution to different plant organs. Hassan et al (2007) showed that vigorous biomass accumulation could lead to the dilution of plant nitrogen content up to the panicle initiation stage, which could lead to inefficient use of $\mathrm{N}$ for spikelet formation. It is important to increase the efficiency of soil and fertilizer $\mathrm{N}$ by using nutrient efficient varieties. It is hypothesized that the $\mathrm{N}$ use efficiency of the rice plant can be optimized by critical leaf, stem and grain $\mathrm{N}$ content of rice varieties, which improves the efficiency of grain production.

Nitrogen is the most limiting soil nutrient in the rice cultivation system of Sri Lanka. Therefore, the application of soil $\mathrm{N}$ fertilizer (Urea) is essential to increase the paddy yield. In the Sri Lankan rice farming system application of urea is high due to the subsidized fertilizer (Ekanayake 2006) prices and with cash advances as incentives. Department of Agriculture has introduced yield targeted nitrogen application in fertilizer recommendation to suit the different rice-growing systems of Sri Lanka. Application of a high rate of nitrogen affects the crop lodging and susceptibility to the pest and diseases due to the softening plant tissues (Yosida 1981). Yang et al (2003) observed that application of nitrogen affects the grain filling rate, 1000 grain weight and grain-filling duration of the rice panicles. Nitrogen absorbed at the early growth stage is used to produce more straw than grain while $\mathrm{N}$ absorbed at later growth stages is used to produce more grain than straw. Yoshida (1981) reported that the rate of grain filling and 1000 grain weight is important traits of rice varieties that determine nitrogen response. In rice production, milling quality is an important factor that determines the income of farmers whereas head rice is the primary factor that determines the world market price of the rice.

The significance of time of nitrogen application on rice growth, yield and nitrogen efficiency was reported by many authors. The key pe- riod for nitrogen absorption by rice plants is from tillering to flowering, during this period the absorption of soil nitrogen is at its maximum rate (Qiao-gang et al 2013).

Hirzel et al (2011) have confirmed high productivity of flooded rice in Chile with the split application of nitrogen as $33 \% \mathrm{~N}$ at sowing, $33 \%$ at tillering, and $34 \%$ at panicle initiation, or $50 \% \mathrm{~N}$ at sowing and $50 \%$ at panicle initiation when $\mathrm{N}$ fertilizer was added to the rate of 140 or $160 \mathrm{~kg} \mathrm{ha}^{-1}$. The low grain yield recorded for the basal application of the entire recommended dose at planting could be due to low available nitrogen due to loss by denitrification, leaching and volatilization. Qiao-gang et al (2013) reported the highest loss of nitrogen due to ammonia volatilization from basal fertilizer application. According to this observation, it could provide the timely application of urea is essential for better production. This study was, therefore, designed to investigate the effect of time of nitrogen application on rice growth, yield and yield components.

Understanding the response of nitrogen application on grain filling and grain yield under local conditions is important to determine the response compared to newly developed elite breeding line At 081078 and standard variety At 362. Detailed studies on these subjects have not been conducted so far under Sri Lankan conditions. Regarding that, an experiment was conducted to find out the effect of nitrogen application on grain filling rate, yield and other grain quality parameters of newly improved rice line compared standard variety with.

\section{MATERIALS AND METHODS}

The experiment was conducted at the research field of the Rice Research Station, Ambalantota (area lies between latitude $60.130 \mathrm{~N}$ and longitude $810.032 \mathrm{~W}$ ) in 2017 Maha season with one elite red pericarp breeding line crossed to At 362/At 358//At 362/IRBB 59 (At 08 1078) and red pericarp standard variety (At 362) of three and half month of growth duration (Table 
1). Five nitrogen levels; 0, 50, 100, 150, and $200 \mathrm{~kg} \mathrm{~N} \mathrm{ha}^{-1}$ were used and treatments arranged in a split-plot design with 3 replicates which was executed after 2, 4, 6, and 7 weeks. Reddish-brown and half bog soil type were recognized in the experimental site. The gross plot area and net plot area were $18 \mathrm{~m}^{2}$ and $12.96 \mathrm{~m}^{2}$. Respectively main plots were separated by a ridge ( $40 \mathrm{~cm}$ in width). Phosphorus (45 kg ha ${ }^{-1} \mathrm{P}_{2} \mathrm{O}_{5}$ as triple superphosphate) was applied as the basal dressing and potassium $\left(20 \mathrm{~kg} \mathrm{ha}^{-1} \mathrm{~K}_{2} \mathrm{O}\right.$ as Muriate of potash) was applied to all the plots after four and six weeks from sowing. The main irrigation water supply was done through the Ridiyagama tank and was provided separately for each plot avoiding contaminations using a specially constructed bund system. Sixty-five panicles that headed on the same day from each subplot were chosen and tagged by waxed labels. Eight tagged panicles from each subplot were collected at four-day intervals commencing from $5 \%$ heading to maturity and considered for further analysis and data collections. A total number of grains of each panicle was separated manually and dried at $70{ }^{\circ} \mathrm{C}$ for $72 \mathrm{hrs}$ and 1000 grain weights were recorded and the grain filling curves were plotted. The grain filling rate was calculated using the following equation.
Grain filling rate $(\mathrm{g} /$ day $)=$

$$
\frac{\text { Increase of } 1000 \text { grain weight }(\mathrm{g})}{\text { number of days taken to grain filling }}
$$

Other growth parameters such as plant height, number of tillers per square meter, number of panicle and number of grain in each panicle were counted manually. Ten to fifteen numbers of seeds from different treatments were taken separately to measure grain length and width (with and without husk). After harvesting, straw weight and grain yield (moisture level at $12 \%$ ) were measured. After dehusking the paddy brown rice content and hardness (Hardness tester model no 174886 Japan) were determined. Lodging was assessed following the guidelines of the International Rice Research Institute (Standard evaluation system 2013). Analysis of variance was performed using STAR for Windows version 2.0.1(IRRI 2014). All graphical designs were done using the Microsoft Excel 2010 version.

\section{RESULTS AND DISCUSSION}

Figures $1 \mathrm{~A}$ and $\mathrm{B}$ illustrate the thousand-grain weight (TGW) of the elite line At 081078 and the variety At 362. TGM values increased from heading until the $32^{\text {nd }}$ day irrespective of the nitrogen levels or varieties (Table 2). At

Table 1: Comparison between elite breeding line At 081078 and standard variety At 362

\begin{tabular}{lll}
\hline Plant characters & At 08 1078 & At 362 \\
\hline Grain length with husk $(\mathrm{mm})$ & 8.49 & 8.97 \\
Grain width with husk $(\mathrm{mm})$ & 2.80 & 2.72 \\
Pericarp colour & Red & Red \\
Grain colour & Straw & Straw \\
Grain type & Long medium & Long medium \\
Panicle type & Intermediate & Intermediate \\
Grain shattering $(\%)$ & 6.0 & 7.7 \\
Number of spikelets $/$ panicle (total) & 136 & 169 \\
Culm length $(\mathrm{cm})$ & 68.5 & 69.0 \\
Basal leaf sheath colour & Green & Green \\
Stigma colour & White & White \\
Dormancy period $($ weeks $)$ & $3-4$ & $3-4$ \\
Panicle number $/ 900 \mathrm{~cm}^{2}($ per $30 \times 30 \mathrm{~cm})$ & 32 & 30 \\
\hline
\end{tabular}


the onset of heading (at $5 \%$ ) the TGW of every treatment was significantly equal in At 08 1078 (ranged from 2.95 to $3.27 \mathrm{~g}$ ) and At 362 (ranged from 2.96 to $3.13 \mathrm{~g}$ ). The TGM difference was noticeable $(\geq 0.05)$ after 8 days of heading in grains fertilized with 100 or more than $100 \mathrm{~N} \mathrm{ha}^{-1}$. This pattern of TGW differences was observed in both elite breeding line At 081078 and standard variety At 362. After 12 days of heading significant increase of grain filling rate was observed in high $\mathrm{N}$ treatments $\left(\geq 100 \mathrm{~kg} \mathrm{~N} \mathrm{ha}^{-1}\right)$ and both varieties showed the same pattern of increase in grain filling rate within different $\mathrm{N}$ levels (Figure 1). However, there was no significant difference between 150 and $200 \mathrm{~kg} \mathrm{~N}^{-1}$ rates on grain filling rates except after 20 days of heading in At 081078 (Figure 1).

Guohui et al (2018) have reported the completion of grain filling of the spikelet in 19 days after heading under low nitrogen application $\left(21 \mathrm{~kg} \mathrm{~N} \mathrm{ha}^{-1}\right)$ and 23 days under the high nitrogen application. This study gives a different picture of grain filling where it has taken 32 days to complete the grain filling under each $\mathrm{N}$ level and the TGW at the completion was almost the same at 150 and $200 \mathrm{~kg} \mathrm{~N} \mathrm{ha}^{-1}$ levels (Table 2). However, the grain filling rates of varieties between $\mathrm{N}$ treatments were quite similar after 28 days of heading (Figure 1). A similar finding of Wickremasinghe

Table 2: Variation of 1000 paddy grains weight from $\mathbf{5 \%}$ heading to maturity of the newly improved elite breeding line (At 08 1078) and stranded variety (At 362)

\begin{tabular}{|c|c|c|c|c|c|c|}
\hline \multicolumn{7}{|c|}{ Elite breeding line At 081078 - 1000 grain weight (g) } \\
\hline \multirow{2}{*}{$\begin{array}{l}\text { Days from } \\
5 \% \text { headings }\end{array}$} & \multicolumn{6}{|c|}{ Nitrogen level kg ha ${ }^{-1}$} \\
\hline & N0 & N50 & N100 & $\mathrm{N} 150$ & $\mathrm{~N} 200$ & $\mathrm{CV}(\%)$ \\
\hline $\mathbf{0}$ & $2.95^{\mathrm{a}}$ & $2.99^{\mathrm{a}}$ & $3.27^{\mathrm{a}}$ & $3.19^{\mathrm{a}}$ & $3.18^{\mathrm{a}}$ & 5.28 \\
\hline 4 & $3.11^{\mathrm{bc}}$ & $3.44^{\mathrm{ab}}$ & $3.67^{\mathrm{a}}$ & $2.97^{\mathrm{c}}$ & $3.36^{\mathrm{b}}$ & 9.17 \\
\hline 8 & $8.16^{\mathrm{b}}$ & $7.98^{\mathrm{b}}$ & $9.89^{\mathrm{a}}$ & $9.90^{\mathrm{a}}$ & $10.56^{\mathrm{a}}$ & 12.91 \\
\hline 12 & $11.73^{\mathrm{b}}$ & $13.86^{\mathrm{b}}$ & $13.43^{\mathrm{b}}$ & $14.44^{\mathrm{a}}$ & $14.61^{\mathrm{a}}$ & 9.10 \\
\hline 16 & $14.90^{\mathrm{c}}$ & $16.47^{\mathrm{bc}}$ & $17.71^{\mathrm{ab}}$ & $17.63^{\mathrm{ab}}$ & $18.53^{\mathrm{a}}$ & 3.27 \\
\hline 20 & $17.32^{\mathrm{d}}$ & $19.03^{\mathrm{c}}$ & $20.82^{\mathrm{b}}$ & $22.60^{\mathrm{a}}$ & $22.01^{\mathrm{a}}$ & 4.05 \\
\hline 24 & $17.87^{\mathrm{d}}$ & $19.60^{\mathrm{c}}$ & $21.65^{\mathrm{b}}$ & $22.49^{\mathrm{ab}}$ & $22.81^{\mathrm{a}}$ & 3.28 \\
\hline 28 & $18.25^{\mathrm{d}}$ & $19.55^{\mathrm{c}}$ & $21.74^{\mathrm{b}}$ & $22.53^{\mathrm{ab}}$ & $23.10^{\mathrm{a}}$ & 3.27 \\
\hline 32 & $19.12^{\mathrm{c}}$ & $21.22^{\mathrm{b}}$ & $22.58^{\mathrm{ab}}$ & $23.71^{\mathrm{a}}$ & $23.74^{\mathrm{a}}$ & 8.54 \\
\hline \multicolumn{7}{|c|}{ Variety At 362 - 1000 grain weight (g) } \\
\hline \multirow{2}{*}{$\begin{array}{l}\text { Days from } \\
5 \% \text { headings }\end{array}$} & \multicolumn{6}{|c|}{ Nitrogen level $\mathrm{kg} \mathrm{ha}^{-1}$} \\
\hline & N0 & $\mathrm{N} 50$ & N100 & $\mathrm{N} 150$ & $\mathrm{~N} 200$ & $\mathrm{CV}(\%)$ \\
\hline $\mathbf{0}$ & $3.09^{\mathrm{a}}$ & $3.07^{\mathrm{a}}$ & $3.12^{\mathrm{a}}$ & $3.13^{\mathrm{a}}$ & $2.96^{\mathrm{a}}$ & 6.78 \\
\hline 4 & $3.17^{\mathrm{bc}}$ & $3.39^{\mathrm{ab}}$ & $3.45^{\mathrm{a}}$ & $3.03^{c}$ & $3.64^{\mathrm{a}}$ & 6.79 \\
\hline 8 & $8.25^{\mathrm{b}}$ & $8.70^{b}$ & $11.35^{\mathrm{a}}$ & $10.40^{\mathrm{a}}$ & $11.56^{\mathrm{a}}$ & 13.98 \\
\hline 12 & $12.24^{\mathrm{b}}$ & $14.07^{\mathrm{b}}$ & $15.69^{\mathrm{ab}}$ & $14.54^{\mathrm{ab}}$ & $14.94^{\mathrm{ab}}$ & 10.54 \\
\hline 16 & $15.93^{c}$ & $16.40^{\mathrm{bc}}$ & $17.89^{\mathrm{ab}}$ & $18.12^{\mathrm{ab}}$ & $19.10^{\mathrm{a}}$ & 6.90 \\
\hline 20 & $18.19^{\mathrm{d}}$ & $18.92^{\mathrm{c}}$ & $20.90^{b}$ & $21.96^{\mathrm{a}}$ & $23.34^{\mathrm{a}}$ & 3.91 \\
\hline 24 & $18.51^{\mathrm{d}}$ & $19.84^{\mathrm{c}}$ & $22.02^{b}$ & $22.34^{\mathrm{ab}}$ & $23.46^{\mathrm{b}}$ & 2.84 \\
\hline 28 & $18.50^{\mathrm{d}}$ & $19.86^{\mathrm{c}}$ & $22.05^{\mathrm{b}}$ & $22.61^{\mathrm{ab}}$ & $23.53^{\mathrm{a}}$ & 3.03 \\
\hline 32 & $19.12^{\mathrm{c}}$ & $22.34^{\mathrm{b}}$ & $24.37^{\mathrm{ab}}$ & $24.67^{\mathrm{a}}$ & $24.45^{\mathrm{a}}$ & 7.26 \\
\hline
\end{tabular}

Note: Mean values with the same letter (s) are not significantly different in each row $(\alpha=0.05, \mathrm{CV}$ - coefficient of variance) 
(1987) stated that TGW was higher when plants were treated with high nitrogen levels (225 urea $\mathrm{kg} \mathrm{ha}^{-1}$ or $105 \mathrm{~kg} \mathrm{~N} \mathrm{ha}^{-1}$ ) and up to certain nitrogen levels may enhance the grain filling period of some rice varieties. A related study by Aobu-Khalifa (2012) have stated the significant increase of TGW and grain filling rate with the application of different soil nitrogen levels on improved rice varieties in Egypt such as Sakha 105, Sakha 106, GZ 7565, GZ 9075 and GZ 9362.

Nitrogen is an essential element of chlorophyll production and affects the increase of chlorophyll pigments in the plant cells which helps to boost up the light reaction of the photosynthetic process and thereby induce the carbohydrates production (Qiao-gang et al 2013).

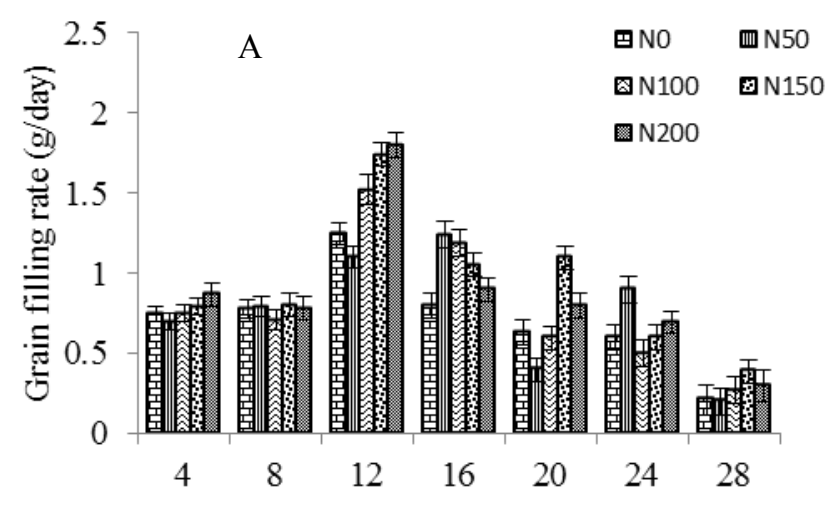

Time taken to grain filling (days) - At 081078
Figure $1 \mathrm{~A}$ and $\mathrm{B}$ show the grain filling rate of rice as grams per day for 1000 grains. According to that, from heading to the end of the grain filling there was a variation in grain filling rate at each nitrogen level throughout the growth. At 12 days after heading the increase of weight per day is the highest recorded weight of $2.0 \mathrm{~g}$ and $1.9 \mathrm{~g}$ in At 081078 and At 362 respectively. As there is no significant increase of grain filling rate or TGW between high $\mathrm{N}$ levels $\left(100,150\right.$ and $\left.200 \mathrm{~kg} \mathrm{~N} \mathrm{ha}^{-1}\right)$ application of nitrogen at the rate of $100 \mathrm{~kg} \mathrm{~N}$ $\mathrm{ha}^{-1}$ found to be the optimum level of $\mathrm{N}$ for At 081078 and At 362.

Adigrat University and Humera Agricultural Research Center collaboratively experimented to observe the yield response of rice with different nitrogen levels, according to the results

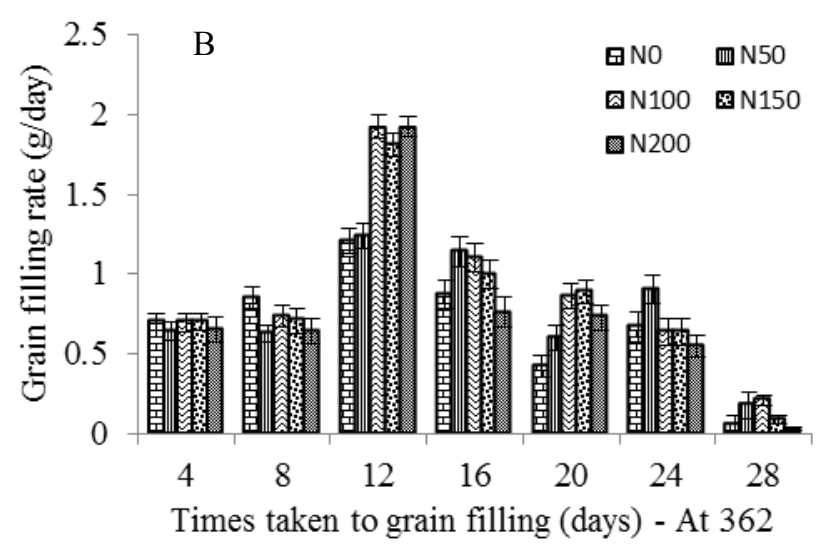

Figure 1: Grain filling rates g/per day for 1000 grains (A - At 081078 and B - At 362)
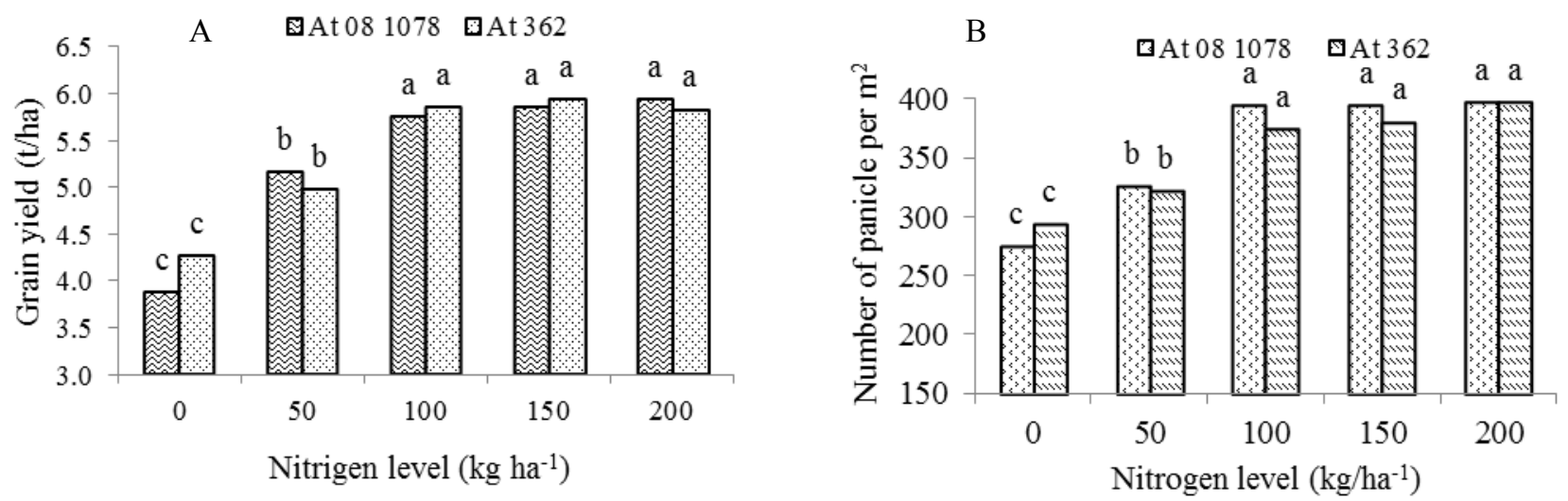

Figure 2: Variation of rice grain yield (A) and number of panicles per $\mathrm{m}^{2}$ (B) of At 081078 and At 362 with different nitrogen levels 
it was shown that grain yield was increased maximally at the recommended level $(95 \mathrm{~kg}$ $\mathrm{N} \mathrm{ha}^{-1}$ ) of $\mathrm{N}$-fertilizer application and a further increase in $\mathrm{N}$ has not given any yield improvement (Gebrelibanos et al 2016). Figure $2 \mathrm{~A}$ illustrates the grain yield of rice varieties at each $\mathrm{N}$ level. Compared to the control treatment $\left(0 \mathrm{~kg} \mathrm{~N} \mathrm{ha}{ }^{-1}\right)$ yield obtained from other treatments was high $(\geq 0.05)$. Along with the increase of $\mathrm{N}$ level from $0 \mathrm{~kg} \mathrm{~N} \mathrm{ha}^{-1}$ to $100 \mathrm{~kg}$ $\mathrm{N} \mathrm{ha}^{-1}$ grain yield has improved from $3.9 \mathrm{t} \mathrm{ha}^{-1}$ to $5.9 \mathrm{t} \mathrm{ha}^{-1}$ in At 081078 and from $3.9 \mathrm{t} \mathrm{ha}^{-1}$ to $5.9 \mathrm{t} \mathrm{ha}^{-1}$ in At $362(\geq 0.05)$. But, the addition of $150 \mathrm{~kg} \mathrm{~N} \mathrm{ha}^{-1}$ or $200 \mathrm{~kg} \mathrm{~N} \mathrm{ha}^{-1}$ has not influenced the grain yield further in both varieties (Figure 2A). Elite breeding line At 08 1078 and standard variety At 362 showed similar grain yield response under each $\mathrm{N}$ level consecutively 100, 150 and $200 \mathrm{~kg} \mathrm{ha}^{-1}$ (Figure 2A). A related experimental outcome was observed by Gebrelibanos et al (2016). Saha et al (1998) also show that panicle formation and differentiation ability with the application of different rate of soil nitrogen which affecting grain filling and yield response which was comparable to this study.

Variation in the number of panicles per unit area $/ \mathrm{m}^{2}$ (Figure $2 \mathrm{~B}$ ) was observed with different nitrogen levels. It was observed that the number of panicles increased with increasing nitrogen levels which had been significant at $100 \mathrm{~kg} \mathrm{~N} \mathrm{ha}^{-1}$ and thereafter it was constant with further application of soil N. Gebrelibanos et al (2016) showed that the number of

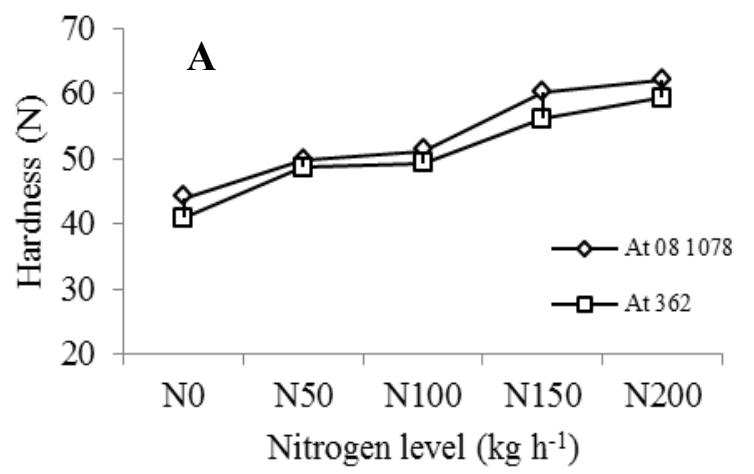

active panicles per unit area increased with increasing level of soil $\mathrm{N}$ where the similar trend was observed in this study as well. Hirzel et al (2011) further confirmed the above findings of $\mathrm{N}$ requirement for panicle production of rice with the application of different rates of urea. According to that the optimum level of urea application was found to be 255 $\mathrm{kg} \mathrm{ha}^{-1}$ and no enhancement in panicle number at further addition of urea.

The grain hardness of brown rice (Figure 3A) increased with increasing level of nitrogen, which resulted due to the compaction of the carbohydrate grain molecules in the seeds; similarly Keeling et al 1988 found carbohydrate compaction in wheat grains. It was observed that the increment in hardness values with increasing level of nitrogen. Elite breeding line At 081078 shows higher hardness compared to the At 362 .

An increase in the percent of brown rice was accounted with increasing the level of soil nitrogen (Figure 3B). The high brown rice content of a variable represents the high milling yield which is favourably considered by rice millers. As reported by Chandel et al (2010) the brown rice grain protein content has increased significantly $(1.1 \%$ to $7.0 \%)$ under higher nitrogen fertilizer application of $120 \mathrm{~kg} / \mathrm{hm}^{2}$. In addition, Resurreccion et al (1979) have found that the brown rice with higher protein content was more resistant to abrasive milling than brown rice with lower

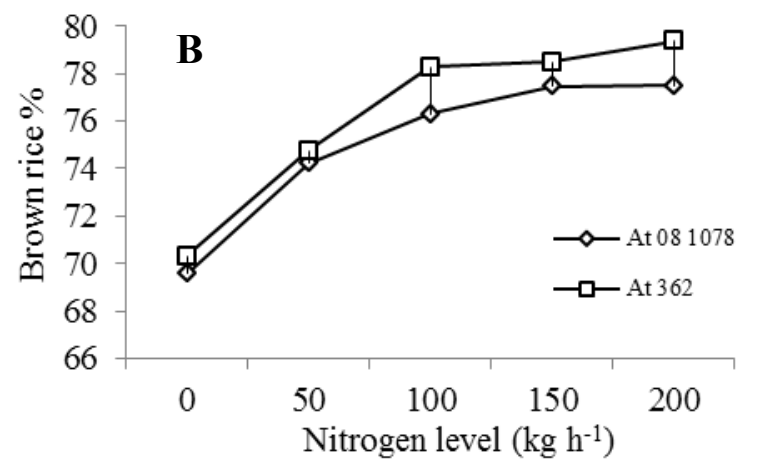

Figure 3: Variation of hardness (A) and brown rice \% (B) of At 081078 and At 362 at different nitrogen levels 
protein in the same variety. Therefore, an increase of soil nitrogen to an optimal level would be favourable to have high milling out turn. The tested two varieties presented a similar trend in brown rice enhancement with nitrogen application but, At 362 had given more brown rice compared to At 081078 at the optimum level $\left(100 \mathrm{~kg} \mathrm{~N} \mathrm{ha}^{-1}\right)$ of nitrogen application.

Table 3 describes the variation in mean plant height as a growth parameter of At 081078 and At 362 during $6^{\text {th }}$ week after sowing to $14^{\text {th }}$ week. By the end of the $10^{\text {th }}$ week, where the vegetative growth comes to its maximum height, plants have reached is the plateau. But, there are variations in plant heights within nitrogen levels. Most of the time when the nitrogen levels higher the plant height has increased. In this study, it was shown that application of $100 \mathrm{~kg} \mathrm{~N}^{-1}$ significantly increased the plant height and further increasing of soil nitrogen levels as at 150 and $200 \mathrm{~kg} \mathrm{~N}$ $\mathrm{ha}^{-1}$ were not significantly affected on plant height. Confirming the great plant biomass
Gebrelibanos et al (2016) also observed the variation of plant height with different soil nitrogen levels. Each variety showed an increasing trend in plant height with the increase of nitrogen, straw yields were recorded high $(\geq 0.05)$ is treated with high nitrogen $(\geq 100$ $\left.\mathrm{kg} \mathrm{N} \mathrm{h}{ }^{-1}\right)$. Straw weight increased continuously with increasing soil nitrogen level.

The number of spikelets per panicle varied within nitrogen levels. Varieties behaved differently at high nitrogen levels. There was a gradual increase in the number of spikelets per panicle with nitrogen level in At 081078 while there was no increase in the number of spikelets per panicle in At 362 beyond $100 \mathrm{~kg}$ $\mathrm{N} \mathrm{h}^{-1}$ level. Ding et al (2014) observed the biosynthesis of Cytokinin in the rice plant with increasing nitrogen fertilizer application rate which influenced to increase in the number of flowers per rice panicle that is comparable to the number of the spikelet of rice panicle.

Paddy grain dimensions such as length and width varied between treatments of nitrogen

Table 3: Variation of growth, yield and quality parameters of rice at different nitrogen levels

\begin{tabular}{|c|c|c|c|c|c|c|}
\hline \multirow[t]{2}{*}{ Growth, yield \& quality parameters } & \multicolumn{6}{|c|}{ Nitrogen levels $\left(\mathrm{kg} \mathrm{ha}^{-1}\right)$} \\
\hline & $\mathbf{0}$ & 50 & 100 & 150 & 200 & $\mathrm{CV} \%$ \\
\hline Plant height (cm) - 6wks (At 08 1078) & $47.50^{\mathrm{c}}$ & $50.50^{\mathrm{c}}$ & $61.61^{\mathrm{b}}$ & $65.61^{\mathrm{a}}$ & $68.94^{\mathrm{a}}$ & 9.21 \\
\hline Plant height (cm) - 6wks (At 362) & $45.57^{\mathrm{c}}$ & $50.27^{\mathrm{c}}$ & $59.94^{\mathrm{b}}$ & $60.50^{\mathrm{b}}$ & $65.16^{\mathrm{a}}$ & 10.00 \\
\hline Plant height (cm) - 8wks (At 08 1078) & $61.50^{\mathrm{c}}$ & $75.47^{\mathrm{b}}$ & $84.97^{\mathrm{a}}$ & $80.17^{\mathrm{a}}$ & $80.77^{\mathrm{a}}$ & 7.75 \\
\hline Plant height (cm) - 8wks (At 362) & $75.95^{\mathrm{c}}$ & $78.88^{\mathrm{b}}$ & $79.63^{\mathrm{b}}$ & $85.20^{\mathrm{a}}$ & $84.55^{\mathrm{a}}$ & 10.71 \\
\hline Plant height (cm) - 10wks (At 08 1078) & $68.06^{\mathrm{c}}$ & $88.00^{\mathrm{b}}$ & $88.90^{\mathrm{b}}$ & $89.85^{\mathrm{b}}$ & $96.93^{\mathrm{a}}$ & 3.63 \\
\hline Plant height (cm) - 10wks (At 362) & $72.76^{\mathrm{c}}$ & $86.41^{\mathrm{b}}$ & $89.22^{\mathrm{a}}$ & $91.50^{\mathrm{a}}$ & $89.88^{\mathrm{a}}$ & 5.80 \\
\hline Plant height (cm) - 12wks (At 08 1078) & $67.22^{\mathrm{c}}$ & $85.66^{\mathrm{b}}$ & $89.18^{\mathrm{b}}$ & $89.18^{\mathrm{b}}$ & $99.61^{\mathrm{a}}$ & 4.63 \\
\hline Plant height (cm) - 12wks (At 362) & $74.44^{\mathrm{b}}$ & $88.33^{\mathrm{a}}$ & $91.11^{\mathrm{a}}$ & $89.55^{\mathrm{a}}$ & $89.66^{\mathrm{a}}$ & 6.32 \\
\hline Plant height (cm - 14wks (At 08 1078) & $75.27^{\mathrm{c}}$ & $80.14^{\mathrm{b}}$ & $91.54^{\mathrm{a}}$ & $91.80^{\mathrm{a}}$ & $96.30^{\mathrm{a}}$ & 8.01 \\
\hline Plant height (cm) - 14wks (At 362) & $73.06^{\mathrm{c}}$ & $83.26^{\mathrm{b}}$ & $88.72^{\mathrm{a}}$ & $89.77^{\mathrm{a}}$ & $93.58^{\mathrm{a}}$ & 5.94 \\
\hline Straw weight (kg) At $081078 /$ net plot area & $5.65^{\mathrm{e}}$ & $8.37^{\mathrm{d}}$ & $12.60^{\mathrm{c}}$ & $15.07^{\mathrm{b}}$ & $17.47^{\mathrm{a}}$ & 7.79 \\
\hline Straw weight (kg) At $362 /$ net plot area & $5.9^{\mathrm{d}}$ & $8.64^{\mathrm{c}}$ & $13.3^{\mathrm{b}}$ & $16.66^{\mathrm{a}}$ & $17.23^{\mathrm{a}}$ & 8.56 \\
\hline Number of spikelets per panicles (At 08 1078) & $88.33^{\mathrm{c}}$ & $91.33^{\mathrm{c}}$ & $94.33^{\mathrm{b}}$ & $92.33^{\mathrm{b}}$ & $122.66^{\mathrm{a}}$ & 12.15 \\
\hline Number of spikelets per panicles (At 362) & $78.53^{\mathrm{c}}$ & $106.00^{\mathrm{b}}$ & $112.00^{\mathrm{a}}$ & $113.66^{\mathrm{a}}$ & $116.66^{\mathrm{a}}$ & 9.59 \\
\hline Seed length with husk At $081078(\mathrm{~mm})$ & $8.46^{\mathrm{c}}$ & $8.82^{\mathrm{a}}$ & $8.49^{c}$ & $8.88^{\mathrm{a}}$ & $8.65^{\mathrm{b}}$ & 11.80 \\
\hline Seed width with husk At 081078 (mm) & $2.71^{b}$ & $2.72^{b}$ & $2.80^{\mathrm{a}}$ & $2.80^{\mathrm{a}}$ & $2.79^{\mathrm{a}}$ & 9.36 \\
\hline Seed length with husk At 362 (mm) & $8.64^{\mathrm{c}}$ & $8.53^{\mathrm{c}}$ & $8.97^{\mathrm{a}}$ & $8.69^{b}$ & $8.82^{b}$ & 1.74 \\
\hline Seed width with husk At $362(\mathrm{~mm})$ & $2.60^{\mathrm{c}}$ & $2.61^{\mathrm{c}}$ & $2.72^{\mathrm{b}}$ & $2.99^{\mathrm{a}}$ & $2.77^{b}$ & 6.380 \\
\hline
\end{tabular}

wks- weeks. Note: Mean values with the same letter are not significantly different in each row $(\alpha=$ $0.05, \mathrm{CV}-$ coefficient of variance) 
Table 4: Status of lodging (At 081078 and At 362) under five different $N$ levels

\begin{tabular}{cccccc}
\hline Replicate & N0 & N50 & N100 & N150 & N200 \\
\cline { 2 - 6 } & \multicolumn{5}{c}{ Lodging with different N levels - At 08 1078 } \\
\hline 1 & 1 & 1 & 3 & 1 & 1 \\
2 & 1 & 1 & 1 & 5 & 5 \\
3 & 1 & 1 & 1 & 1 & 1 \\
\hline 1 & 1 & Lodging with different N levels - At 362 & \\
2 & 1 & 1 & 1 & 1 & 5 \\
3 & 1 & 1 & 3 & 5 & 5 \\
\hline
\end{tabular}

Note: No Lodging - (1), Most plant slight lodged (more than 50\%) - (3), Most plants moderately lodged (5), Most plant nearly flat (7), All plants flat (9)

applications. Grain length and width of At 08 1078 ranged from 8.46 to $8.88 \mathrm{~mm}$ and 2.71 to $2.80 \mathrm{~mm}$ respectively. Those dimensions of At 362 ranged from 8.53 to $8.97 \mathrm{~mm}$ and 2.60 to $2.99 \mathrm{~mm}$. Compared to the paddy grains of the control treatment $\left(0 \mathrm{~kg} \mathrm{~N} \mathrm{~h}^{-1}\right)$ nitrogen treated plots with $\geq 100 \mathrm{~kg} \mathrm{~N} \mathrm{~h}^{-1}$ had larger grain dimensions (Table 3).

Application of soil nitrogen fertilizer affects the cell division and tissues development of the plants and over dosage of urea application influence tissue softening (Yosida 1981) thereby crop lodging is persuaded. Table 4 shows that the lodging status of At 081078 and At 362 with five different nitrogen levels. However, partial lodging of both varieties was reported at $100 \mathrm{~kg} \mathrm{~N} \mathrm{ha}^{-1}$ level and further increases of soil nitrogen level as 150 and 200 $\mathrm{kg} \mathrm{N} \mathrm{ha}{ }^{-1}$ were reported to partially or fully lodging as table 4 .

\section{CONCLUSION}

Lowest grain yield 3.9 and $4.3 \mathrm{t} / \mathrm{ha}$ were reported at $0 \mathrm{~kg} \mathrm{~N} \mathrm{ha}^{-1}$ level in At 081078 and At 362 respectively. Grain yield and yield components were significant at $100 \mathrm{~kg} \mathrm{~N} \mathrm{ha}^{-1}$ with increasing the nitrogen rate of both elite breeding line At 081078 and variety At 362 . Grain filling rate was significant at the $100 \mathrm{~kg}$ $\mathrm{N}$ ha ${ }^{-1}$ and which lowest at the $0 \mathrm{~kg} \mathrm{~N} \mathrm{ha}^{-1}$. Over dose $\left(\geq 100 \mathrm{~kg} \mathrm{~N} \mathrm{ha}^{-1}\right)$ of soil nitrogen was not significantly improved the yield, yield components and grain quality of both At 08 1078 and At 362. Application of urea as nitrogen fertilizer at the rate of $100 \mathrm{~kg} \mathrm{~N} \mathrm{ha}^{-1}$ was given as significant level for grain filling, yield and growth parameters of both varieties.

\section{REFERENCES}

Abou-Khalifa AAB 2012 Evaluation of some rice varieties under different nitrogen levels. Pelagia Research Library, Advances in Applied Science Research, USA, 3 (2):1144 - 1149.

Chandel G, Banerjee S, See R, Meena D, Sharma J, Verulkar SB 2010 Effects of different nitrogen fertilizer levels and active soil properties on rice grain $\mathrm{Fe}$, $\mathrm{Zn}$ and protein contents. Rice Science. 17(3): 213-227.

Ding C, You J, Chen L, Wang S and Ding Y 2014 Nitrogen fertilizer increases spikelet number per panicle by enhancing Cytokinin synthesis in rice. Plant Cell Report. 33: 363 - 371.

Ekanayake HKJ 2006 The impact of fertilizer subsidy on paddy cultivation in Sri Lanka. The Central Bank of Sri Lanka. 74- 96.

Gebrelibanos G and Fisseha B 2016 Response of rice yield and yield parameters to timings of nitrogen application in Northern Ethiopia. International Journal of Engineering Development and 
Research. 4 (4): 897-900.

Guohui L, Qiuqian H, Yange S, Kehui C, Lixiao Nie, Jianlian $\mathrm{H}$ and Shaobing Peng 2018 Low Nitrogen Application Enhances Starch-Metabolizing Enzyme Activity and Improves Accumulation and Translocation of Non-structural Carbohydrates in Rice Stems. Journal of Front Plant Sci. 9: 1- 15.

Hassan MS, Abul Khair, Haque MM and Abdul Hamid 2007 Photosynthetic characters, SPAD value and nitrogen use efficiency of traditional AUS rice (Oryza Sativa L.) cultivars. SAARC Journal of Agriculture. 5 (2): 29- 40.

Hirzel J, Pedreros A and Cordero K 2011 Effect of nitrogen rates and split nitrogen fertilization on grain yield and it's components in flooded rice. Chilean Journal of Agricultural Research. 71(3): 437444.

International rice research institute, Los Banos, Philippines Star for Windows version 2.0.1(IRRI, 2014) .

Keeling PL, Wood JR, Tyson RH and Bridges IG 1988 Starch biosynthesis in developing wheat grain. Evidence against the direct involvement of Triose phosphates in the metabolic pathway. Plant Physiol. 87: 311-.319.

Qiao-gang Y, Jing Y, Shao-na Y, Jian-Rong F, Jun-Wei M, Wan-Chun S, Li-Na J, Qiang W and Jian-Mei W 2013 Effects of nitrogen application level on rice nutrient uptake and ammonia volatilization. Rice Science. 20(2): 139-147.
Resurreccion AP, Juliano BO, Tanaka Y 1979 Nutrient content and distribution in milling factors of rice grain. Journal of the Science of Food and Agriculture. 30: 475:481.

Saha A, Sarkar RK and Yamagishi Y 1998 Effect of time of nitrogen application on spikelet differentiation and degeneration of rice. Botanica Bulletin - Academia Sinica Taipei. 39: 119-123.

Standard evaluation system for rice, International rice research institute, $5^{\text {th }}$ edition, Los Banos, Philippines (IRRI, 2013).

Wickremasinghe WMADB 1987 Preliminary studies on sink source relationship of some rice varieties under different fertilizer regimes. Proceeding of Rice Research Workshop on 16 - 17 June 1987 at central rice breeding station, Batalagoda, Ibbagamuwa, Sri Lanka, 169$189 \mathrm{pp}$.

Yang WH, Peng S, Huang J, Sanico AL, Buresh AL, Witt C 2003 Using leaf colour chart to estimate leaf nitrogen status of rice, Agriculture Journal. 95: 212-217

Yoseftabar S 2013 Effect of nitrogen management on panicle structure and yield in rice (Oryza sativa L.). International Journal of Agricultural Crop Science. 5 (11): 1224-1227.

Yoshida S 1981 Fundamentals of rice crop science. International rice research institute, Los Banos, Philippines: 135 pp. 